\title{
DETERMINANTS OF HOUSEHOLD FOOD SECURITY IN THE EASTERN REGION OF NEPAL
}

\author{
G. R. Joshi ${ }^{* 1}$ and N. B. Joshi ${ }^{2}$ \\ ${ }^{1}$ Commissioner, Commission for the Investigation of Abuse of Authority, Nepal \\ ${ }^{2}$ President, Sustainable Research and Development Center, Kathmandu, Nepal
}

\begin{abstract}
Using the agricultural census data of 2011/12, this paper has attempted to identify the determinants of household level food security in the eastern region of Nepal. Being the censored type sample population, tobit model has been used. On an average, the households experienced no food shortages for 8.5 months, the cultivated land per household was 0.85 hectare and around 34 percent of the cultivated land was irrigated. The results showed that the size of the land holding, nearness to the market, male headed household, households members with agriculture and allied occupation and the educational level of household head were positive and significant variables while household size was negative and significant variable to food security. It was also revealed that the hills and the mountains were more food insecure than Terai region. Hence, investment in human capital, creation of off-farm employment opportunities, increasing physical access through markets and roads development and access to land and augmenting their quality are needed to further improve the food security situation. Similarly, special programs should be implemented targeting female headed households as they are more food insecure than male headed households.
\end{abstract}

Keywords: Determinants, food security, household, eastern region, Nepal

\section{INTRODUCTION}

The subject of food insecurity has attracted attention of the world, given its direct link to malnutrition. According to Collins (2005), food insecurity is linked to acute and chronic physical and mental health conditions such as higher levels of stress, anxiety, irritability, social isolation, heightened emotional responsiveness, eating disorders, depression as well as impaired cognitive abilities. This is harmful to human capital formation as it can ultimately result in low labor productivity. The undesirability of food insecurity due to its negative effect on the livelihoods and

* Corresponding author email: grjoshi20@gmail.com

Received: 23.10 .2016 
economy has prompted governments to commit themselves for achieving food security through food self-sufficiency given the unreliability of imports.

Food insecurity is increasing in the world where 795 million people are suffering from hunger. Out of them, about 780 million people are living in developing countries. Compared to other regions, the progress towards reducing the number of hunger and malnourished people has been slow in South Asia and subSaharan Africa. The highest burden of hunger occurs in South Asia, where as many as 281 million people are undernourished (FAO, 2015).

Agriculture provides livelihood to over 60 percent of the economically active population and contributes about one-third to GDP in Nepal (MoF, 2013). The structure of the economy of Nepal has been changed slightly over the years. The share of agriculture in GDP fell by 10 percent over a period of about 20 years (44 percent in 1990-92 to 34 percent in 2012-13).

The average rate of real AGDP growth during 1984 to 1998 remained at 2.35 percent per annum which is slightly above the population growth. However, there was an improvement in AGDP growth from 1999 to 2014 which was 3.62 percent per annum. It is also evident that this growth is fluctuating from year to year which was 4.3 percent in 2000/01, 1 percent in 2006/07, 5 percent in 2011/12, and 1.9 percent in 2014/15. The main reason for the poor performance was the adverse weather condition that affected the production of cereal crops, cash crops, vegetables and livestock.

In Nepal, better performance of agriculture is not only necessary for sustained high growth of the economy but also for ensuring food security and reducing rural poverty. Poor agricultural performance could not deliver added purchasing power for better living of the average Nepali people during the recent years causing a slowdown in demand leading to a further sluggish growth of the economic activities. The nonagricultural sector also witnessed a decelerating growth due to mainly sluggish industrial activities followed by suppressed demand in the domestic market and contracting external market as well.

In Nepal, 76.3 percent of households are agricultural households. Compared to 1995/96, the percentage of agricultural households operating land has been decreased in 2010/11. The area of irrigated land, on the other hand, has been increased during the same period. Between 1995/96 and 2010/11, the number of households that operate less than 0.5 hectare of land has been increased by 13 percentage points. On the other hand, number of households with 2 ha or more operated land has been decreased from 12 percent in 1995/96 to 4 percent in 2010/11 (CBS, 2011).

Average landholding size in Nepal is declining from 1.13 ha in 1981 to 0.79 ha in 2001 and 0.68 ha in 2011. The size of landholding and food self-sufficiency has a positive correlation. Only 5 percent of the households with less than 0.1 ha are food self sufficient from their own production while over 60 percent of them are self sufficient with holding above 0.5 hectare (CBS, 2013). 


\section{Food security policy}

The concept of food security encompasses multiple dimensions such as food production, access and absorption. Factors that may lead to a situation of food insecurity, therefore, mainly include non-availability of food, lack of access to food and improper utilization of food. Hence, the determinants of household food security in effect comprise the factors that determine each component of food security. In general, the determinants of food security are different at different levels of application, i.e., global, national, regional, household and individual level (Khan et al., 2012).

The relationship between poverty, food insecurity, and nutrition is strong. Poor households often lack the resources required to access and consume sufficient nutritious food to live a healthy active life. Based on 2010 estimates, Nepal's GDP per capita (PPP) of 1,200 USD ranks $206^{\text {th }}$ out of 227 countries worldwide. According to the third Nepal Living Standard Survey, 25.2 percent of the population is estimated to live below the poverty line (CBS, 2011).

A commonly held belief that food insecure regions in Nepal generally produce less and, therefore, consume less of their own production than in other areas. The difference in overall adequacy of consumption between regions is largely a result of households in more food secure regions purchasing more food and more diverse food than those in less food secure areas. Household food purchases are facilitated by improved market access, including physical and financial access (NPC, 2013).

The Government of Nepal (GoN) has prepared various instruments related to poverty and hunger. During the 1970s, incorporating marginalized people into political agendas and policies related to access were framed (Adhikari and Bohle, 1999). The Agricultural Perspective Plan (APP) implemented from the Ninth FiveYear Plan focused on incremental improvement of food production in Nepal with an aim to help marginal farmers (NPC, 1995). Moreover, since the 1980s, GoN has been providing subsidies in transportation to help food reach people in the food-deficit areas.

Pursuant to the World Food Summit Rome Declaration 1996, Millennium Development Goal (MDG) targets (1990-2015), the Government of Nepal adopted the food and nutrition security agenda in the Ninth Plan (1997-2002). To address this, various strategies and programs were being implemented in a limited scale.

Efforts were made to address food security issues and concerns in periodic plans after the people's movement of 2006. The main objectives for the agriculture sector as expressed in the Three Year Plan (2010/11-12/13) were to ensure food and nutrition security; make agricultural sector competitive; reduce poverty by increasing employment and income generating opportunities; and minimize adverse effects of environment, climate variability and climate change. 
The food and nutrition security objective of the thirteenth plan ( 2013/14 to 2015/16) is to increase the supply of basic foodstuffs through increasing the productivity of agriculture and livestock products; and ensure the food security of vulnerable area and groups by increasing their access to food items ( NPC, 2014). Further, the Constitution of Nepal 2015 aims for food sovereignty of the people as per the law.

\section{Status of food security}

According to World Food Summit (1996), food security is meant when all people at all times have physical and economic access to sufficient, safe, and nutritious food which meets their dietary needs and food preferences for active and healthy life. Access to an adequate supply of food is the most basic human need and right. There are four most important elements of food security, namely, food availability, food access, food utilization, and stability based on which one can easily find out the situation of food security. Food availability at the national level, food access to households and its utilization by an individual are the core aspects of food security.

Nepal has relatively poor yields for key cereal crops compared to its neighbors. The cereal balance is determined by the production of five major cereal crops: paddy, maize, millet, wheat, and barley. In recent years, potato production has become more important, especially in mountain areas. The overall national cereal balance has been positive in most the years since 2000, with the exceptions of 2006/07 and 2009/10 when drought affected production.

Aggregate food availability per capita depends on the population and total domestic food production. Food availability in Nepal is aggravated by a myriad of complex issues, including but not limited to waning agricultural production rates, rising population pressure, and declining soil quality. Food production is being altered by scarce water resources too as the major staple food of the country like rice requires huge amount of water. Moreover, the increasing demand has to be fulfilled from same amount of agricultural land. The ratio of agricultural land to total land is lowest in Nepal i.e., only 35 percent (Rasul and Schild, 2009) where as this ratio is highest in Bangladesh (70 percent). A growing number of studies from Nepal suggest that in some areas, more than 30 percent of total cultivated land has been abandoned (Khanal and Watanabe, 2006).

The available information shows that per capita per annum edible food grain availability decreased from $198 \mathrm{~kg}$ during 1990/91 to $183 \mathrm{~kg}$ in the year 1998/99. This slightly rose to $190 \mathrm{~kg}$ in 2005/06, again declined to $186 \mathrm{~kg}$ in 2006/07 and $2008 / 09$, further declined to $177 \mathrm{~kg}$ in 2009/10 and increased to $196 \mathrm{~kg}$ in 2014/15 (MoAD, 2014; DoA, 2015 ). Food production growth in Nepal is subdued by the closing land frontier, lack of desired growth in agricultural productivity, and unfavorable trade balance for the import of food. Of these, low crop productivity and its underlying causes has significance policy relevance. The part of the deficit is 
fulfilled from the sources like potato, meat, fish, egg, etc. Out of 75 districts, 45 were found to be food deficit during 2008/09 which declined to 31 in 2014/15. Due to unequal distribution of land and production constraints, the mountains and the hills are more hit by food deficit. Almost all the mountains and some hilly districts are food insecure for the last decades or so. The access to food is considered as the most basic human need and right. This has been affected by the distribution of resources and their productive capacity. Hunger and malnutrition are pervasive across Nepal, it has affected certain groups of people and households more than others. Within the ecological belt, the people of one community are hungrier than those of other community depending upon social and economic status. Although Nepal was considered as a food exporting country till mid 1980s, gradual rise in imports is evident since 1991. Moreover, the production of major food grains has the coefficient of variation ranging from 11-20 percent during recent decades, indicating that the scenario was not favorable in terms of stability in production. Factors contributing to these annual variations are the inadequacy of irrigation infrastructure and its ineffective management, ineffective service delivery, and increased incidence of natural calamities such as drought and flood.

The distribution of income (in nominal terms) as per CBS (2011) revealed that the bottom 80 percent of the population earn about 44 percent of total income while the top 20 percent earn the other 56 percent of total income. The poorest 10 percent of the total population accounts for less than 2 percent of total income whereas the richest 10 percent of the population accounts for 40 percent of the total income. At the national level, 28 percent of all household income comes from agriculture, 37 percent from nonfarm enterprises, 17 percent from remittances, and 16 percent from own housing consumption.

The share of consumption from own production and market purchases vary by ecological region. In the mountains, the bulk of food consumed is from households' own production. The average household consumes 53 percent from their own production, 40 percent from purchased food, and 7 percent in-kind. In the hills, households purchase the bulk of food consumed. The average household consumes 40 percent from their own production, 57 percent from purchased food, and 2 percent in-kind. Households in the Terai purchase the bulk of food consumed. The average household consumes 43 percent from their own production, 54 percent from purchased food, and 3 percent in-kind (CBS, 2011).

Nepal ranked at $58^{\text {th }}$ position among 104 countries in terms of Global Hunger Index (GHI). The score is getting improved from 44.5 in the year 1990 to 31.6 in 2005 and a score of 22.2 in the year 2015 (IFPRI, 2015).

Several studies were carried out to identify the determinants of food security in many different contexts using different variables and analytical techniques. Those studies have considered variables related with household characteristics such as family size, gender, educational attainment and age of household head; economic 
variables such as size of the land holding, nature of the ownership of the assets, offfarm/non-farm income sources, consumption pattern, food and input prices; and others related to markets and infrastructures such as access to markets, availability of marketing infrastructures and roads, extension services, etc.

A study by Bashir et al. (2013) in Pakistan revealed that livestock assets, education, no. of income earners in a household have a positive impact while family size and household heads' age had a negative impact on food security. Sultana and Kiani (2011) in Pakistan found that place of residence (Urban) and dependency ratio has a significant and negative effect while educational attainment level of household's head beyond intermediate level has significant and positive impact on food security status of household. Faridi and Wadood (2010) in Bangladesh showed that total land owned by the household, electricity connection, household size, household heads' occupation, and safety net programs had a strong impact on food security situation.

The studies carried out in Ethiopia revealed that the variables affecting household food insecurity were size of the cultivated land, livestock holding and improved seed sex of household head, soil fertility status and non-farm income (Abdullah, 2015). The cultivated land holding size, total livestock holding, total annual income, and use of fertilizer were positive to food security while family size of the household was negative variable (Asmelash, 2014). Similarly, a study by Beyene and Muche (2010) showed that the variables such as experiences in farming activities, off-farm and non-farm incomes, land and livestock holdings, use of chemical fertilizer, and soil and water conservation practices significantly affected household food security.

A study by Habyarimana (2015) in Rwanda indicated that households headed by females were more likely exposed to food insecurity than those headed by males. Zakiri et al. (2014) in Niger revealed that the gender of the head of household, diseases and pests, labor supply, flooding, poverty, access to market, the distance away from the main road and food aid were significant factors influencing the household having enough daily rations. Similarly, female headed households were more vulnerable to food insecurity compared to male headed households.

Joshi et al. (2012) in Nepal demonstrated that family size, operational landholding and livestock holding were important determinants of food insecurity, whereas, dependency ratio and occupation were important determinants of income poverty. Education of household head and landholding were important determinants for both income and consumption poverty. Maharjan and Joshi (2011) concluded that the main factors contributing to food insecurity in Nepal were limited access to resources, illiteracy, big family size, higher dependency ratio, dependency on agriculture with small landholding, limited access to irrigation and fertilizer, and dependency on wage labor. With these characteristics, the highest proportion of 
occupational caste households and households in the mountain and hill were chronically food insecure.

The review of past studies indicate that multiple and interrelated factors determine the household food security that might vary from one to other contexts. The quantitative analyses of the factors affecting the household food security in Nepal are very limited and also differ in terms of analytical methods used. This study is designed to fill this gap to a limited extent.

Considering the above fact in mind, this paper aims to analyze the trend in production and productivity of major crops, review and assess the food security more specifically the situation of household food security by ecological regions and identify its determinants in the eastern region of Nepal.

\section{MATERIALS AND METHODS}

\section{Data sources}

The study utilized the latest agricultural census data for 2011/12 collected by the Central Bureau of Statistics (CBS). Three districts in the eastern development regions namely Taplejung, Panchthar and Jhapa each representing mountains, hills and Terai ecological region of Nepal, respectively were purposively selected. The basic sampling methodology used was a two-stage area sampling, as follows:

In the first stage, selection of a stratified sample of enumeration areas (EAs) with probability proportional to the expected number of holdings (stratified PPS sampling);

In the second stage, within selected EAs, the selection of a sample agricultural holding using stratified systematic random sampling. The EAs were defined as wards (smallest administrative and political units) contained less than 25 holdings or may be more than 25 but less than or equal to 30 holdings if wards are combined. Between 20 and 30 holdings were selected in each selected EA (CBS, 2013). For this study, 18 EA from Taplejung (from 1 to 18) with holdings of 430, 22 EA from Panchthar (from 1 to 22) with holdings of 516 and 19 EA from Jhapa (from 1 to 19) with holdings of 426 were selected with a total sample size of 1372 holdings.

\section{Analytical method}

Many socioeconomic and demographic features of farm households affect the food security and food availability. In order to analyze the patterns and extent of food security, the limited dependent variable model also known as Tobit model can be employed.

To model the effect of different factors on household food self-sufficiency, a Tobit model was used. This is represented below using an index function approach

$$
\begin{aligned}
& \mathrm{V}_{\mathrm{i}}{ }^{*}=\beta^{\mathrm{T}} \mathrm{X}_{\mathrm{i}}+\varepsilon_{\mathrm{i}} \\
& \mathrm{V}_{\mathrm{i}}=0 \text { if } \mathrm{V}_{\mathrm{i}}^{*} \leq 0
\end{aligned}
$$




$$
\mathrm{V}_{\mathrm{i}}=\mathrm{V}_{\mathrm{i}}^{*} \text { if } \mathrm{V}_{\mathrm{i}}^{*}>0
$$

where $\mathrm{V}_{\mathrm{i}}$, a limited dependent variable, is the perceived situation of food security; $\mathrm{V}_{\mathrm{i}}{ }^{*}$ is an underlying latent variable that indexes food security; $\mathrm{X}$ is the vector of socioeconomic and demographic characteristics of the farm household, $\beta^{T}$ is a vector of parameters to be estimated; and $\varepsilon_{\mathrm{i}}$ is an error term. The Tobit model has an advantage in that its coefficients can be further disaggregated to determine the effects of a change in the $\mathrm{i}^{\text {th }}$ variable on change in the probability and intensity of being food security.

Since the sample population is the censored type (no. of months the household is food self-sufficient; which is from 0 to 12), the OLS estimation of the censored regression model generates biased and inconsistent parameter estimates. Therefore, the tobit model was used to examine the factors influencing the household food security. The LIMDEP econometric package was used to derive the MLE estimates and marginal effects of tobit regression analysis. The sign of the marginal effect coefficient indicates the directional effect of each individual variable, while the magnitude of effect can be judged from the value of the estimated coefficient. The value of marginal effect coefficient implies the changes in percentage of household being food secure brought about by one unit change in explanatory variable ceteris paribus. The t-statistic was used to judge the significance of each explanatory variable while the Log-likelihood Ratio (LR) test was employed to judge the effect of all variables included in the model (overall fit of the model) on the proportion households being food secure. The LR is computed as

$$
\begin{gathered}
W=-2\left(\log L_{o}-\log L_{\text {Max }}\right) \\
\text { Where } \log \mathrm{L}_{\mathrm{o}}=\log \text { likelihood function of the fitted model } \\
\text { When all coefficients except the constant are constrained to } 0 ; \\
\log \mathrm{L}_{\max }=\log \text { likelihood function of the fitted model which includes all the } \\
\text { parameters constant terms }\left(\beta_{1}\right) \text { and all other parameters }\left(\beta_{2}, \beta_{3}, . . \beta_{\mathrm{k}}\right) .
\end{gathered}
$$

\section{RESULTS AND DISCUSSION}

\section{Dietary energy intake}

According to 2010/11 Nepal Living Standard Survey, the national average dietary energy (Kcal) intake is 2,536 Kcal per capita per day; a level that is higher than the minimum average adequate requirement of $2,220 \mathrm{Kcal}$ set by the Government of Nepal (CBS, 2011). There is no significant difference in average dietary energy intake between urban and rural areas. In urban areas, 43 percent of the population consume less than the national minimum caloric threshold compared to 37 percent in rural areas. However, when interpreting this result, it is important to consider that national thresholds set by the government of Nepal are based on "light activity" and the energy demands for a healthy active life in rural areas typically 
exceed those in urban areas due to increased activity. As such, the data may underestimate the real magnitude of energy deficiency in rural areas.

Food energy intake varies significantly between Nepal's geographic regions (Table 1). The greatest per capita intake of calories is in the rural Terai -Central $(2,762 \mathrm{Kcal}$ per day), compared to the lowest per capita intake in the rural Hills - mid and far western (2,331 Kcal per day).

Table 1. Average energy intake in Nepal

\begin{tabular}{lcc}
\hline Population & $\begin{array}{c}\text { Average kilocalories } \\
\text { consumed per capita per day }\end{array}$ & $\begin{array}{c}\text { Percent of the population } \\
\text { food energy deficient }\end{array}$ \\
\hline Nepal & $\mathbf{2 5 3 6}$ & $\mathbf{3 8}$ \\
Urban & 2525 & 43 \\
Rural & 2539 & 37 \\
Regions & & \\
Mountains & 2403 & 45 \\
Urban - Kathmandu & 2481 & 53 \\
Urban - Hill & 2524 & 42 \\
& & 38 \\
Urban -Terai & 2553 & 43 \\
Rural Hills - Eastern & 2542 & 45 \\
Rural Hills - Central & 2422 & 42 \\
Rural Hills - Western & 2452 & 49 \\
Rural Hills - Mid and & & 28 \\
Far Western & 2331 & 23 \\
Rural Terai - Eastern & 2640 & 34 \\
Rural Terai - Central & 2762 & 37 \\
Rural Terai - Western & 2590 & \\
Rural Terai - Mid and & 2515 & \\
Far Western & & \\
\hline
\end{tabular}

Source: CBS, 2011

\section{Production and yield of major crops}

In Nepal, the rice, maize, wheat and potato are the major food crops. These crops covered nearly 71 percent of the total cropped area and account nearly 73 percent of the production of food crops including vegetables (MoF, 2015). The area, production and yield of these crops are presented in table 2. It shows that the area expansion was the major contributor to the increased production in the first period for 
almost all the crops. The contribution of yield growth to total production growth was higher for all crops except potato in the second period compared with the first period. The contribution of yield growth to total production was 134 percent, 79 percent, 63 percent and 43 percent for paddy, maize, wheat and potato, respectively.

Table 2. Annual compound growth in area, production and yield (in \%)

\begin{tabular}{lllllll}
\hline \multirow{2}{*}{ Crops/Period } & \multicolumn{3}{c}{$1984-1998$} & \multicolumn{3}{c}{$1999-2013$} \\
\cline { 2 - 7 } & $\mathrm{A}$ & $\mathrm{P}$ & $\mathrm{Y}$ & $\mathrm{A}$ & $\mathrm{P}$ & $\mathrm{Y}$ \\
\hline Paddy & 0.60 & 2.12 & 1.52 & -0.38 & 1.11 & 1.49 \\
Maize & 2.14 & 3.83 & 1.69 & 0.67 & 3.15 & 2.48 \\
Wheat & 2.09 & 4.34 & 2.25 & 1.19 & 3.22 & 2.03 \\
Potato & 4.00 & 7.47 & 3.47 & 3.44 & 6.04 & 2.60 \\
\hline
\end{tabular}

Note: $\mathrm{A}=$ Area; $\mathrm{P}=$ Production; and $\mathrm{Y}=$ Yield.

\section{Household characteristics}

On an average, the family size was 5 persons, the age of the household head was 47 years, 19 percent of the households were headed by female and the education level of the household head was about 4 years of schooling. The percentage of female headed household was the highest in Taplejung while the education level of the household head was the highest (5 years of schooling) in Jhapa district (Table 3).

Table 3. Socio-demographic Characteristics of the Household

\begin{tabular}{lllll}
\hline Districts & $\begin{array}{c}\text { Family } \\
\text { size (no.) }\end{array}$ & $\begin{array}{c}\text { Age of the } \\
\text { household } \\
\text { head (Years) }\end{array}$ & $\begin{array}{c}\text { \% of Female } \\
\text { headed } \\
\text { household }\end{array}$ & $\begin{array}{c}\text { Education level of the } \\
\text { Household Head (years } \\
\text { of schooling) }\end{array}$ \\
\hline Taplejung & 4.96 & 47.1 & 24.4 & 3.1 \\
Panchthar & 4.55 & 46.3 & 18.6 & 3.7 \\
Jhapa & 5.33 & 48.7 & 13.6 & 5.1 \\
Average & 4.93 & 47.3 & 18.9 & 3.9 \\
\hline
\end{tabular}


On an average, the households experienced no food shortages for 8.5 months, the cultivated land per household was 0.85 hectare, around 34 percent of the cultivated land was irrigated, about 86 percent households were having allied activities along with agricultural occupation (Table 4).

Table 4. Holding size, food self-sufficiency and related information

\begin{tabular}{lcccc}
\hline Districts & $\begin{array}{c}\text { Holding } \\
\text { size (ha.) }\end{array}$ & $\begin{array}{c}\text { \% area } \\
\text { irrigated }\end{array}$ & $\begin{array}{c}\text { Average food } \\
\text { insufficiency } \\
\text { (months) }\end{array}$ & $\begin{array}{c}\text { \% of households with } \\
\text { agriculture and allied } \\
\text { activities }\end{array}$ \\
\hline Taplejung & 0.99 & 32.9 & 2.7 & 96.5 \\
Panchthar & 0.80 & 16.6 & 3.8 & 94.0 \\
Jhapa & 0.78 & 54.3 & 3.9 & 80.8 \\
Average & 0.85 & 33.6 & 3.5 & 93.5 \\
\hline
\end{tabular}

\section{Result of the quantitative analysis}

The result of the Tobit regression (Table 5) showed that the size of the land holding, nearness to the market, male headed household and households members with agriculture and allied occupation were significant at 1 percent probability level while the educational level of household head was significant at 5 percent probability level. All these variables contributed positively to the household food security. The household size variable (family size) was highly significant at 1 percent level but negatively related with food security. The livelihood ratio was found highly significant which implies that level of food security was explained by the significant explanatory variables. The pseudo R-square was also 0.70 .

Male-headed households are in a better position in terms of food security than the female headed ones. The result was found to be consistent with the hypothesis showing positive influence of sex of household head (HHHEAD dummy) on food security status at one percent probability level. This result is consistent with the findings of Abdullah (2015) and Habyarimana (2015).

The household head education (education) largely contributed on working efficiency, competency, diversify income, and adopting technologies with long term target to ensure better living condition than illiterate ones. Similarly, the women are less educated and have less access to technologies and other income opportunities than man. This is consistent with the findings of Bashir et al. (2013) and Sultana and Kiani (2011).

The land is considered as the principal asset in rural areas of Nepal. The size of the land holding by the household was found to have positive and significant relationship (at one percent probability level) with the food security. The bigger the 
size of land holding (land holding), the more food secure the households. The possible explanation for this relationship could be that the major source of food in the study districts comes form own production and there was limited opportunities for getting involved in other income generating activities. So the household who own have large land holding size has better production which gives a better chance for the household to be food secured. This result is in agreement with the findings of Abdullah (2015), Asmelash (2014) and Faridi and Wadood (2010).

There was significant (at one percent probability level) positive relationship of household members with agriculture and other income sources (agriculture and other sources) with the food security. The diversification of the employment opportunities among the members of the households reduces the risk of income generation and hence contributed to food security. This might be due to the fact that households engaged in non-farm activities are better endowed with additional income and more likely to escape food insecurity. Similarly the smallholders who solely depend on farm activities have inadequate income to purchase farm inputs and fulfill family needs and thus, they are found to be food insecure. This finding is consistent with the findings of Abdullah (2015), and Beyene and Muche (2010).

The household size (family size) was negative and significant with the food security. This implies that existence of a large number of family members in household results into food insecurity compared to the small family size. The reason is that the households who depend on limited productive resources (such as land) will face food insecurity with increasing family size. This is consistent with the finding of Asmelash (2014), Bashir et al. (2013).

The nearness of the households to the market centers (market distance) facilitates the buying of households needs and selling of the home produced products. This is consistent with the findings of Zakari et a1. (2014).

The ecological region dummy (ECODUMMY) variable ( 1 for the hills and mountains and 0 otherwise) was found negative but highly significant which implies that the hills and the mountains are more food insecure than Terai region. Two variables namely the age of the household head (AGE HHHEAD) and dummy variable for the ownership of the land (own land dummy - one for owner operator and zero otherwise) were positive but not significant for food security.

Table 5. Factors affecting household food security in eastern Nepal

\begin{tabular}{lc}
\hline Variable & Coefficient \\
\hline Constant & 0.157 \\
HHHEAD DUMMY & $0.053^{* * *}$ \\
AGE HHHEAD & 0.0006 \\
EDUCATION & $0.004^{* *}$ \\
FAMILY SIZE & $-0.008^{* * *}$
\end{tabular}




\begin{tabular}{lc} 
LAND HOLDING & $0.144^{* * * *}$ \\
ECO DUMMY & $-0.057^{* * * *}$ \\
MARKET DISTANCE & $0.018^{* * *}$ \\
AG AND OTHER SOURCES & $0.398^{* * *}$ \\
OWN LAND DUMMY & 0.026 \\
Likelihood Ratio (Chi-square) & $700.87^{* * *}$ \\
Pseudo R-square & 0.70 \\
\hline
\end{tabular}

*** and ** indicate significant at 1 percent and 5 percent probability level.

\section{CONCLUSION}

The Government of Nepal implemented various policies and programs to increase food production and address food insecurity. Despite this, many households living in mountain and hilly areas are still food insecure. The area expansion remained a major contributor to the increased production for major cereal crops before 1999 while the yield growth contributed to total production after 1999. On an average, the households experienced no food shortages for 8.5 months, the size of landholding was small and only around one-third of the cultivated land was irrigated. The study made attempts to identify major factors that might affect the household food security using tobit model. The study revealed that the educational attainment level of household's head positively contributed to enhancing the situation of food security, the female-headed households are more food insecure compared to maleheaded households, although they play major role in household food security. Similarly, the households with bigger size of land holding, nearness to road heads and markets, and the members having off-farm and non-farm occupation contributed positively to food security where as bigger household size contributed negatively to the food security. Therefore, monetary and non-monetary supports should be availed to female headed households to improve their food security. In addition, investment should be increased for improving the education level of the household members, creating off-farm employment opportunities, increasing physical access through markets and roads infrastructures development in the rural areas, and improving access to land and their utilization and developing irrigation facilities to augment their quality will improve the household food security situation in the rural areas of Nepal.

\section{Acknowledgement}

The authors would like to thank the Central Bureau of Statistics for providing data for this study and anonymous reviewers for their comments and suggestions. 


\section{REFERENCES}

Abdulla, A. H. 2015. Determinants of household food security and coping strategies: the case of Bula-hora district, Borana zone, Oromia, Ethiopia. European Journal of Food Science and Technology, 3(3): 30-44

Adhikari, J. and Bohle, H. G.1999. Food Crisis in Nepal. Adroit Publishers, New Delhi

Asmelash, M. 2014. Rural households food security status and its determinants: the case of Laelaymychew Woreda, central zone of Tigrai Ethiopia. Journal of Agricultural Extension and Rural Development, 6(5):162-167

Bashir, M. K., Schilizzi, S. and Pandit, R. 2013. Regional sensitivity of rural household food security: The case of Punjab, Pakistan. The Journal of Animal and Plant Sciences, 23(4):1200-1206

Beyene, F. and Muche, J. 2010. Determinants of food security among rural households of central Ethiopia: An empirical analysis. Quarterly Journal of International Agriculture, 49 (4):299-318

CBS, 2011. Nepal living standards survey 2010-11: Statistical report volume one and two, Central Bureau of Statistics, Nepal

CBS, 2012. Poverty in Nepal 2010/11. Report based on NLSS 2010/11, Kathmandu, Nepal

CBS, 2013. National sample census of agriculture Nepal 2011/12. Central Bureau of Statistics, Kathmandu, Nepal

Collins, I. 2005. Impact of food insecurity on women's mental health: How it negatively affects children's health and development. Journal of the Association for Research and Mothering, 11: 251-262

DoA, 2015. Cereal balance sheet of Nepal 2014/15. Department of Agriculture, Agri-business Promotion and Marketing Development Directorate, Nepal

FAO, 2015. The state of food insecurity in the world. Food and Agriculture Organization of the United Nations, Rome

Faridi, R. and Wadood, S. N. 2010. An econometric assessment of household food security in Bangladesh. The Bangladesh Development Studies, 33(3):97-111

Habyarimana, J. B. 2015. Determinants of household food insecurity in developing countries: Evidences from a probit model for the case of rural households in Rwanda. Sustainable Agriculture Research, 4(2):78-91

IFPRI, 2015. Global Hunger Index: Armed conflict and the challenge of hunger. International Food Policy Research Institute, Washington D. C

Joshi, N. P., Maharjan, K. L. and Piya, L. 2012. Determinants of income and consumption poverty in Far-Western rural hills of Nepal: A binary logistic Regression analysis. Journal of Contemporary India Studies: Space and Society, 2:51-61

Khan, R. E. A., Azid T. and Toseef, M. U. 2012. Determinants of food security in rural areas of Pakistan. International Journal of Social Economics, 39(12): 951-964 
Khanal, N. R. and Watanabe, T. 2006. Abandon of agricultural land and its consequences: A case study in Siklek area, Gandaki Basin, Nepal Himalaya. Mountain Research and Development, 26 (1):32-40

Maharjan, K. L. and Joshi, N. P. 2011. Determinants of household food security in Nepal: A binary logistic regression analysis. Journal of Mountain Science, 8:403-413

MoAD, 2014. Statistical information on Nepalese agriculture 2013/14. Ministry of Agricultural Development, Nepal

MoF, 2013. Economic survey 2012/13. Ministry of Finance, Government of Nepal.

NPC, 1995. Agriculture perspective plan. National Planning Commission, Kathmandu.

NPC, 2013. Nepal thematic report on food security and nutrition. National Planning Commission

NPC, 2014. Thirteenth plan ( 2013/14 to 2015/16). National Planning Commission Rasul, G. and Schild, A. 2009. Food security and agricultural sustainability in South Asia: A mountain perspective. In G. S. Kainath (ed), Food security and sustainability in India, GAD Institute of Development Studies, India

Sultana, A. and Kiani, A. 2011. Determinants of food security at household level in Pakistan. African Journal of Business Management, 5(34):12972-12979

Zakari, S., Ying, L. and Song, B. 2014. Factors influencing household food security in West Africa: The case of Southern Niger. Sustainability, 6:1191-1202 